\title{
Implementation Of Electronic Government At The Department On Integrated One Door Investment And Licensing Services, Deli Serdang Regency
}

\author{
Muhammad Fairuz Arief \\ Department of Public Administration Science, University Of North Sumatra, Indonesia.
}

\begin{tabular}{|c|c|}
\hline ARTICLE INFO & ABSTRACT \\
\hline Article history: & \multirow{4}{*}{$\begin{array}{l}\text { E-government policy is one form of reform in the implementation of } \\
\text { services for the public in Indonesia which aims to improve } \\
\text { effectiveness, efficiency, transparency, and accountability in public } \\
\text { service implementing institutions in terms of achieving organizational } \\
\text { goals. The purpose of this study was to find out how the } \\
\text { implementation of Electronic Government at the Department of } \\
\text { Investment and One Stop Integrated Licensing Services } \\
\text { (DPMPPTSP) Deli Serdang Regency.The method used in this } \\
\text { research is descriptive qualitative. This method aims to explain } \\
\text { reality contextually, interpret phenomena that are of concern to } \\
\text { researchers and understand participants' perspectives on the } \\
\text { problems that occur. The types of data used are primary data and } \\
\text { secondary data. Primary data was obtained through interviews with } \\
\text { resource persons, and secondary data was obtained through } \\
\text { literature and documentation studies. The data analysis technique } \\
\text { used is a model approach with data reduction, data presentation, } \\
\text { and drawing conclusions. The results of this study reveal that E- } \\
\text { government in DPMPPTSP can be implemented quite well from } \\
\text { increasing the effectiveness and efficiency of licensing services. The } \\
\text { communication factors, resources, disposition, and bureaucratic } \\
\text { structure in DPMPPTSP are also quite good. The absence of spatial } \\
\text { planning regulations makes the licensing process inefficient because } \\
\text { it adds to the bureaucracy. DPMPPTSP is advised to provide ICT } \\
\text { technical training to employees so that DPMPPTSP's performance is } \\
\text { even better. }\end{array}$} \\
\hline $\begin{array}{r}\text { Received Nov 06, } 2021 \\
\text { Revised Des 15, } 2021 \\
\text { Accepted Jan 30, } 2022\end{array}$ & \\
\hline Keywords: & \\
\hline $\begin{array}{r}\text { Policy Implementation } \\
\text { E-Government } \\
\text { Public Service }\end{array}$ & \\
\hline
\end{tabular}

This is an open access article under the CC BY-NC license.

\section{Corresponding Author:}

Muhammad Fairuz Arief,

Department of Public Administration Science,

University Of North Sumatra, Indonesia,

JI. Dr. Mansur No. 9 Padang Bulan, Kec. Medan Baru, Kota Medan 20222.

Email: fairuzarief@gmail.com

\section{INTRODUCTION}

A clean and transparent system of government and public services is a challenge that must be answered by government institutions in carrying out their functions. On the other hand, the rapid advancement of information and communication technology opens up opportunities for fast and accurate access, management and utilization of large volumes of information.

One of the public services in Indonesia that has started to use ICT is the online licensing service by the One Stop Integrated Licensing Service (PTSP) in districts/cities in Indonesia, 
including the Office of Investment and One Stop Integrated Service, Deli Serdang Regency. One of the public organizations that also implements E-government in Indonesia is the Deli Serdang Regency Investment and One-Stop Integrated Service Office. Researchers paid attention to PTSP sites in several districts/cities which were not uniform with each other. An example is the Bandung City Government's Integrated Licensing Service website with the link dppt.bandung.go.id, the site is very user friendly because of the minimalist appearance (design) of the website but complete content presented to users (permission applicants).

Websiteowned by the Department of Investment and One Stop Service, Deli Serdang Regency, it doesn't look much different in design from that of the Medan City Government. A site that is too full of information that is not actually needed in licensing activities results in an unattractive appearance because the font size is forced to be small to fill the home page and other pages with all this information. Of course, in the implementation of E-government, not only the existing media but also the quality of both the appearance and the program of the media itself is also part of E-government. Many researchers found on the PTSP Deli Serdang site, such as the few licensing options, the absence of reports on the number of permits that have been issued, the lack of clarity about the length of the licensing process.

\section{RESEARCH METHOD}

The form of this research is qualitative research. The term qualitative research according to Denzin and Lincoln in Moleong (2006:5) states that "qualitative research is research that uses a natural setting, with the intention of interpreting phenomena that occur and is carried out by involving existing methods". Qualitative research methods are often called naturalistic research methods because the research is carried out in natural conditions (natural settings).

Qualitative research method is a research method used to examine the condition of natural objects, (as opposed to an experiment) where the researcher is the key instrument, data collection techniques are carried out by triangulation (combined), data analysis is inductive and qualitative research results emphasize meaning rather than generalization (Sugiyono, 2005:1).

Based on these characteristics, this study uses a qualitative approach that is carried out in natural conditions, is more descriptive in nature, emphasizes the process rather than the product or outcome, conducts data analysis inductively, and emphasizes meaning. Qualitative research was chosen because it can clearly describe the actual state of communication, resources, disposition, and bureaucratic structure in DPMPPTSP Deli Serdang. Qualitative research will explain how the implementation of E-government with the Edward III implementation model chosen by the researchers.

\section{RESULTS AND DISCUSSIONS}

\subsection{Implementation of E-Government in DPMPPTSP}

\section{a. Communication}

Implementation will be effective if the measures and policy objectives are understood by the bureaucrats who are responsible for achieving policy objectives (Keiser and Meier in Hill, 2002: 172). The clarity of the size and objectives of the policy thus needs to be communicated appropriately with the implementers. Consistency or uniformity of the basic measures and objectives need to be communicated so that implementers know the exact size and objectives of the policy. To find out how the communication that occurs in DPMPPTSP researchers conducted observations and interviews how the message was conveyed through the communication channel (transmission), how the recipient of the message caught the message (clarity of information), and the consistency of the message from the past to the latest.

\section{b. Transmission}


The clarity of the size and objectives of the policy thus needs to be communicated appropriately with the implementers. The Government of Indonesia in Presidential Decree No. 97 of 2014 has communicated policies through formal channels down the goals in the service process at PTSP explicitly in Article 18 which is also the standard for PTSP services. This standard is a must for all PTSP in Indonesia to be implemented or implemented. It can be concluded that the consistency or uniformity of the basic measures and objectives have been communicated to the implementers, so that they know the exact size and objectives of the policy. The results of observations show that almost all PTSP official websites in the regions contain at least content that is in accordance with the Presidential Decree No. 97 of 2014 which contains potential and business opportunities; general investment planning; implementation of promotion and economic cooperation; development of investment realization; list of closed business fields and open business fields with conditions; type, technical requirements, mechanism for tracking document position in each process, cost, and service time; complaint service procedures.

DPMPPTSP has accepted, agreed and clearly understands the concepts of E-government desired by the central government. Even DPMPPTSP is ready to innovate to be even better, not just stop because the minimum target from the government has been met (Interview. Head of DPMPPTSP. 9 November 2017).

Communication through formal channels downwards from the central government, the Ministry of Communication and Informatics, the Regent, and within the Deli Serdang DPMPPTSP internally went well. Downward messages mainly contain information that is necessary for any staff to carry out their duties, such as policies and procedures, orders and requests are complete. Law No.32 of 2004 concerning Regional Government, Law No.25 of 2007 concerning Investment, Law no. 25 of 2009 concerning Public Services, Government Regulation No. 41 of 2007 concerning Regional Apparatus Organizations, Presidential Regulation No. 27 of 2009 concerning PTSP in the Investment Sector, Presidential Instruction No. 3 of 2006 concerning Investment Climate Improvement Packages, Permendagri No. 24 of 2006 Concerning the Implementation of One Stop Integrated Public Service, Permendagri No.57 Th. 2007 concerning Technical Guidelines for Structuring Regional Apparatus Organizations, Permendagri No.20 of 2008 concerning Organizational Guidelines and Work Procedures for Integrated Licensing Services in the Regions, Permenpan No.20 of 2006 concerning Public Service Standards, and Deli Serdang Regulation no. 2233 of 2016 has sent messages about the desired policies and procedures to be carried out.

\section{c. Information Clarity}

The information that has been transmitted may not be understood by the implementor because the message conveyed is "ambiguous" or unclear. Especially in formal information channels, if the information received is not clear, it will lead to policy implementation errors and procedural errors.

Formally, the procedure must have been communicated through the Standard Operating Procedure (SOP), but it is often found in some agencies that the SOP is sometimes just a complementary document to fulfill the regulations. Thick SOP documents are sometimes not even read and made only by imitating or quoting from the same agency.

To answer the clarity of the information in the DPMPPTSP, the researchers conducted indepth interviews with officials and staff at the Deli Serdang DPMPPTSP whether they clearly understood the existing policies and procedures and became their main task force.

Clarity of information for the implementation of services electronically is very good. juridically the policy of Presidential Decree No. 97 of 2014 is very clear and does not cause any other meaning and is strengthened again by the Deli Serdang Regional Regulation No. 2233 of 2016. Organizational communication has also been carried out by holding workshops between the central government and PTSP throughout Indonesia. It is not difficult to translate messages from the central government. In simple terms, the message from the policy to be conveyed to the implementor is that PTSPs throughout Indonesia create sites to provide services to service users with a minimum level of publishing and then increasing it to the transaction level.

\section{d. Consistency}


The consistency of communication in the implementation of E-government in the DPMPPTSP is seen by researchers through the communication channels formed in the DPMPPTSP to the central government which owns and issues policies. Is this E-government policy consistent from time to time or is the government "unsettled" to implement it so that there are changes to its policies and procedures.

Consistency is measured not only by the absence of changes that are different from the previous message, but also by looking at its intensity. Messages sent on the communication channel in DPMPPTSP are consistent. There is no change that is "confused" with the messages sent, especially messages from superiors to subordinates (Interview. Head of Sub Division. Planning and Program of DPMPPTSP. 24 October 2017).

PTSP was formed to unite permits that were previously scattered in several offices, agencies, or other government institutions in the regions. The goal is to make it easier for the public to access licensing services so they don't have to go to several places. This delegation of authority has been communicated to the ministry and within the scope of Deli Serdang it has been communicated by the regent and the Deli Serdang Perbup policy No. 2029 of 2016 has been issued which delegates licensing authority to the DPMPPTSP Deli Serdang. However, there are government agencies that have not yet handed over their authority to the DPMPPTSP (interview with the Head of Subsection. Planning and Program of DPMPPTSP, 24 October 2017) which shows an attitude of resistance which will be discussed further in the disposition section.

\subsection{Resource}

It does not matter how clear and consistent the implementation of the program is and how accurately the communications are sent if the personnel responsible for implementing the program are under-resourced to carry out their duties. Edaward III (1980:11) categorizes organizational resources consisting of "Staff, information, authority, facilities, building, equipment, land, and supplies" which the researcher simplifies into 3 parts, namely staff or human resources, authority and infrastructure and budget. . Facilities, buildings, equipment, land and supplies are covered in infrastructure. While information is part of the communication that has been discussed in the previous section. Information is a message that is sent and obtained through communication. If the communication is good and open, it means that the information they have is also good.

\section{a. Human Resources}

The Deli Serdang Regency Investment and Integrated Licensing Service (DPMPPTSP) is supported by an apparatus with a total of 68 (sixty-eight) personnel consisting of 40 (forty) civil servants (PNS) and 28 (twenty-eight) employees. honorary with the following details:

Table 1. Education Level of Civil Servants at DPMPPTSP

\begin{tabular}{ccc}
\hline No. & Education & Amount \\
\hline 1 & Postgraduate (S2) & 5 \\
2 & Bachelor degree) & 20 \\
3 & Diploma 3 (D3) & 4 \\
4 & high school & 11 \\
& Amount & $\mathbf{4 0}$ \\
\hline
\end{tabular}

Source: DPMPPTSP 2017

Table 2. Civil Service Education Discipline at DPMPPTSP

\begin{tabular}{ccc}
\hline No. & Education & Amount \\
\hline 1 & Law & 3 \\
2 & Administration & 8 \\
3 & Economy & 5 \\
4 & Government & 3 \\
5 & Social & 2 \\
6 & Agriculture & 1 \\
7 & technique & 5 \\
8 & Informatics / computer & 2 \\
& Amount & $\mathbf{2 9}$ \\
\hline
\end{tabular}


In addition to the level of education, disciplines are also important to determine the quality of human resources. A field will run well if it is carried out by those who have knowledge and understanding in that field. Right man on the right place do the right job. Most of the disciplines possessed by DPMPPTSP employees come from administration, government, law and economics. Discipline of course in accordance with the needs to take care of licensing and capital in DPMPPTSP. However, to support E-government, it also requires graduates with the ITK discipline, something that DPMPTSP lacks in quantity. For this reason, DPMPPTSP contracted 4 people for the development of E-government applications in DPMPPTSP (Interview. Head of Sub Division. Planning and Programs. 24 October 2017).

Table 3. Honorary Employee at DPMPPTSP

\begin{tabular}{ccc}
\hline No. & Position & Amount \\
\hline 1 & Data Section & 1 \\
2 & Program Section & 1 \\
3 & Finance & 1 \\
4 & General & 1 \\
5 & Front Office & 5 \\
6 & Data Section & 2 \\
7 & Secretariat & 1 \\
8 & Back Office & 8 \\
9 & Senior Officer & 2 \\
10 & IT staff & 2 \\
11 & cleanliness & 3 \\
12 & Night guard & 1 \\
\multicolumn{2}{c}{ Source: DPMPPTSP 2017 } & $\mathbf{2 8}$ \\
\hline
\end{tabular}

DPMPPTSP IT staff consists of 4 people who have the ability to work and innovate. The next development to be achieved is integration with other government agencies or institutions that can assist in the file verification process so that service users do not need to come to the DPMPPTSP office again. This integration takes a long time because it needs to be mutually agreed on how to exchange data and build applications that support it. The IT staff also wants to make a survey application to support the performance of field units. They admit that there are many challenges in developing services electronically and it takes a long time (Interview. IT staff. 24 October 2017).

\section{b. Authority}

Authority is also a very important resource. Authority can simply be interpreted as the ability to make decisions that must be obeyed freely. The Indonesian government since 2003 has issued a policy on the implementation of E-government in the form of Presidential Instruction Number 3 of 2003 concerning National Policies and Strategies for the Development of E-Government to utilize information and communication technology in the government process and create an informationbased Indonesian government that causes every government to be good government at the central and regional levels to compete to introduce information technology into their organizations as in Law no. 32 of 2014 concerning Regional Governments to be able to take care of the administration independently but in an integrated manner.

The establishment of the One Stop Integrated Investment and Licensing Service (DPMPPTSP) Deli Serdang Regency on November 23, 2016 is one manifestation of the realignment of the Organizational Structure and Work Procedures of Regional Apparatuses that had been previously prepared in Deli Serdang Regional Regulation Number 5 of 2007 concerning the Establishment of The Organization and Work Procedures of the Deli Serdang Regency Regional Apparatus and has been amended by Deli Serdang Regency Regional Regulation Number 1 of 2014 concerning Amendments to Deli Serdang Regency Regional Regulation Number 5 of 2007 concerning the Establishment of the Deli Serdang Regency Regional Apparatus Organization and Work Procedure, with the previous Nomenclature of the Deli Serdang Regency One Stop Integrated Licensing Service (BPPTSP) which was formed on January 4, 2016.

The Deli Serdang Regency One Stop Investment and Licensing Service was established based on Deli Serdang Regent Regulation Number 2333 of 2016 concerning Position, 
Organizational Structure, Duties and Functions and Work Procedures of Regional Apparatus. Has the task of coordinating regional policies and services in the field of business licensing and nonbusiness licensing in an integrated manner with the principles of coordination, integration, synchronization, and simplification which is under and responsible to the Regent.

\section{c. Infrastructure and Budget}

The budget in the Deli Serdang DPMPPTSP in 2017 was not prepared for the online licensing application pioneered by the Ministry of Communications and Informatics because it was entered in the middle of the budget period. This automatically creates quite a big problem in DPMPPTSP in terms of preparing the facilities needed to meet the desired service standards. This budget unpreparedness can be seen from the absence of generators and the lack of computer or laptop facilities. When interviewing IT staff Ade Tri Putra asked about the problems they were experiencing, the electricity suddenly went out. According to the IT staff reinforcer, power outages are the number 1 obstacle in DPMPPTSP to provide services to the community (Interview. 11 October 2017). When the power goes out,

Supporting infrastructure in the development of E-government referred to in the Standard Operating Procedures (SOP) for online licensing at the DPMPPTSP office, such as computers, printers, scanners, internet or e-office networks, cameras and finger machines (Observation, October 25, 2017).

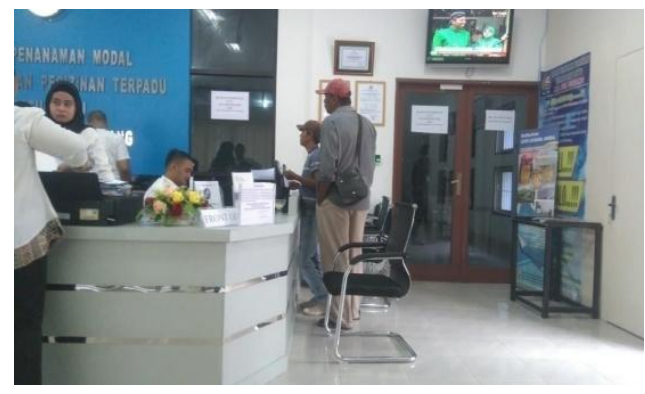

Figure 1. DPMPPTSP Front Office atmosphere

Observation results show that all facilities for the front office are complete as shown in Figure 1. The service room at the permit is quite comfortable, enough seating and using air conditioning. To entertain is also provided a TV.

It can be concluded that the resources owned by DPMPPTSP deli are sufficient, but need to be further improved, especially in the field of facilities and the quality of human resources.

\section{d. Disposition}

The disposition in carrying out online licensing at PTSP must be seen widely because in its implementation the disposition of PTSP as an implementer is not enough to ensure the implementation of services goes well. this disposition broadly involves the central and local governments; SKPD involved in the delegation of authority; and DPMPTSP Deli Serdang.

The central government, represented by the Ministry of Communication and Informatics, has shown its awareness by issuing the SiCantik application which is the basis for applications at PTSP. The central government also encourages by issuing circulars to speed up the process for SKPDs that have not yet submitted documents to PTSP so that they can be followed up. The Regent of Deli Serdang in this case fully supports DPMPTSP to go further. This support is evidenced by the budget of 3.4 billion Rupiah to build a new DPMPPTSP building in order to improve service and employee comfort (Interview. Head of DPMPPTSP. 9 November 2017).

DPMPPTSP regarding the findings of the absence of a spatial regulation that makes it difficult for the Head of the DPMPPTSP to make a decision to approve the permit, the Deli Serdang DPRD has now set up a committee to "work up" the spatial regulation. This is a positive thing considering 
that based on the findings of the researchers, this regulation has long been deadlocked for decades. If the spatial planning regulation has been finalized and ratified, it can be used as a basis that the local government's disposition is to support integrated services at the Deli Serdang DPMPPTSP with an intensive response (Interview. DPMPPTSP person).

The disposition of DPMPPTSP for the implementation of E-government is in the interest of good service. DPMPPTSP also wants the development of applications to separate contact between applicants and employees which is currently still happening to avoid corruption, collusion, and nepotism (Interview. Head of DPMPPTSP 9 November 2017). This strategy is actually not the first time PTSP has done it. As done by the Bandung City Government PTSP, the PTSP has been successful in doing so. even the receipt of files is no longer done at the PTSP Office but is sent via post (Observation. 25 October 2017).

The long-term plan that the Head of DPMPPTSP Deli Serdang wants to carry out is also in line with what was conveyed by the IT staff, namely "our future direction is integration first, so later we can enter files without going to the office. We don't know if the file is genuine or fake if it's not confirmed by the person who issued the file" (Interview with IT staff. 24 October 2017). For technical field, IT staff also plans to make an E-survey which will be used by survey officers.

DPMPPTSP realizes that there are regions that are better at implementing online licensing, therefore each region must cooperate and help each other to improve the quality of licensing services in all regions in Indonesia. DPMPPTSP also in this comparison is not only trying to improve the quality of its own service, but also helping other PTSPs. This is evidenced by carrying out the Workshop on Application of Perininan from the Regency/City and the Signing of the Cooperation Pact on the Development and Submission of the Deli Series Source Code with 39 Regencies/Cities. This workshop is the submission of the Deli Series, namely the SiCantik application from the Ministry of Communication and Information that has been developed by DPMPPTSP Deli Serdang then for 9 days training is given how to use it.

\subsection{Bureaucratic Structure}

Discussing the implementing agency of a policy cannot be separated from the bureaucratic structure. Bureaucratic structures are characteristics, norms, and patterns of relationships that occur repeatedly in executive bodies that have both potential and real relationships with what they have and run policies (Annisa, 2011: 31).

Bureaucratic structure is a fundamental factor for reviewing the implementation of public policy. According to Edward III in Winarno (2005: 150) there are two main characteristics of the bureaucracy, namely: "Standard Operational Procedure (SOP) and fragmentation".

\subsection{Standard Operational Procedure}

Standard Operating Procedures (SOPs) are not foreign to government organizations. DPMPPTSP already has an SOP with ISO 9001:2015 quality assurance. Of course the SOP is something that must be found in any government agency, including the DPMPPTSP Deli Serdang. The SOPs in the DPMPPTSP are basically SOPs submitted by the related SKPDs that used to take care of permits. The DPMPPTSP SOP only underwent minor changes in several parts, one of which was in the part of signing the permit by the regent to being the signatory of the permit by the Head of DPMPPTSP. The SOP also does not change with the presence of electronic services. There is no change in the procedure at all, only the way it works is slightly different, such as the signing of a permit by the Head of DPMPPTSP does not need to be "wet", but can be done through the "smart phone" belonging to the Head of DPMPPTSP.

To get closer and improve services to the community and shorten the service process, the Government of Indonesia issued Presidential Decree No. 97 of 2014 concerning the Implementation of One Stop Services. This Presidential Decree unifies the process of managing licensing and non-licensing services which were previously separated in several institutions or ministries to be managed by only one agency. In Chapter V Article 17 it is explained that the implementation of licensing and non-licensing by PTSP is required to use Electronic Services (PSE), even in it the minimum criteria that PSE must possess, namely: potential and business opportunities; general investment planning; implementation of promotion and economic 
cooperation; development of investment realization; list of closed business fields and open business fields with conditions; jeis, technical requirements, document position tracking mechanism in each process, cost, and service time; complaint service procedures; and other matters regulated in the Perpu.

\subsection{Fragmentation}

The second characteristic of the bureaucratic structure that influences policy implementation is fragmentation. Edward III in Winarno (2005:155) explains that "fragmentation is the distribution of responsibility for a policy to several different agencies that require coordination". In general, the greater the coordination required to implement policies, the less likely the program or policy will be successful. This is quite interesting in the implementation of integrated services which can simply be said to take over tasks in several agencies/institutions but must continue to coordinate with these agencies/institutions.

The head of the DPMPPTSP Deli Serdang said that the DPMPPTSP only issued the permit but that supervision and guidance remained with the relevant agencies (Interview. 9 November 2017). This coordination also has an even line of coordination or in other words, no one is higher or lower so that it can have adverse consequences as stated by Winarno (2005:154) if fragmentation is seen as narrow by some parties, namely first, "there is no strong authority in policy implementation due to the division of certain functions into different institutions or agencies. In addition, each agency has limited jurisdiction over a certain area, so important tasks may be neglected in various piled up bureaucratic agendas. Second, a narrow view of the body which may also hinder change. If an agency has low flexibility in its missions, it will try to maintain its essence and will likely oppose new policies that require change.

In the third and fourth stages of the licensing process, to increase the accountability of the survey. It is also necessary to form an application that can monitor survey results so that applicants can protest if the survey results are not valid and the surveyors also increase their accountability because they can directly monitor their performance in the field if they make mistakes or falsifications whose track record can be directly traced. The last stage of the licensing process is payment and collection of permits. Currently, payments at DPMPPTSP can be made at the office or via transfer to Bank Sumut. To avoid direct contact at this stage, several PTSPs cooperate with sending services such as POS, TIKI, JNE, and so on. By increasing the application's ability to confirm payments through the Bank of North Sumatra which also involves integration with the Bank, the vision to eliminate direct contact between applicants and DPMPPTSP employees can be fully realized.

The implementation of E-government for the implementation of public services in DPMPPTSP is quite good. Support from higher and equal institutions, capacity that can still be improved, and benefits have been felt by the community.

\section{CONCLUSION}

Presidential Regulation No. 97 of 2014 as a result of the revision of Presidential Regulation no. 27 of 2009 requires all PTSPs including DPMPPTSP Deli Serdang to provide services electronically which has been implemented quite well by DPMPPTSP Deli Serdang. It is concluded with various observations of concepts used by researchers to see the implementation of E-government, namely:

Communications that occur in the implementation of policies for implementing E-government in the DPMPPTSP involve the central government to regional SKPDs whose duties are taken over by the DPMPPTSP. Communication that occurred based on the results of observations during the study, both from the central and local governments went very well in terms of transmission, clarity, and consistency. This good communication is also shown by the uniformity of information circulating up to the DPMPPTSP as well as in SKPD whose duties are taken over, namely to improve services by providing services electronically and placing permits in an integrated manner, processed by only one agency and still coordinating with related parties. .

Resources are often the main problem in implementing government policies in Indonesia. This is also felt in the implementation of E-government at DPMPPTSP Deli Serdang. Human resources, 
infrastructure, superstructure, information and authority have been observed by researchers with some major notes on human resources and infrastructure. Training to improve the ability and work discipline of employees and the procurement of generators to ensure there are no obstacles in providing them are things that need to be done so that the concept of this resource goes from just being enough to being good.

In Deli Serdang's DPMPPTSP itself, based on the observations of researchers at the institution, there is no need to question their disposition. Being appointed by the KPK to be a PTSP pilot in other regions in Indonesia is proof that there is more desire to be better by innovating. The application from the Ministry of Communications and Informatics was further upgraded by the Deli Serdang DPMPPTSP to Deli Series and then distributed free of charge to 39 other districts/cities and the Deli Serdang DPMPPTSP also participated in guarding and assisting the development of applications in these districts/cities by establishing intense communication through facilities. telecommunications and the formation of Whatsapp groups so that fellow PTSPs participating in the workshop can exchange information regarding licensing applications.

The disposition to implement E-government also involves the same bureaucratic line as the communication concept, which needs to be sorted from the center to the technical institutions. At the level of the central government when withdrawn from the issuance of Presidential Instruction No. 2003. 3, it is seen that the attitude of the central government is less clear. Even Presidential Regulation No. 97 of 2014, the central government can only present applications to provide services electronically in mid-2017. In other words, there is a large gap in the implementation of egovernment in the central government itself which affects the performance of PTSP in Indonesia.

The disposition at the Deli Serdang regional government level has been very good with the full support of the DPMPPTSP. When it was found that there was no spatial regulation, the government moved quickly and actively. The regional government of Deli Serdang also maintains an intense relationship with the KPK to increase transparency and accountability in the DPMPPTSP.

The problem with disposition is that there are SKPDs that are late in handing over their authority to the DPMPPTSP. If there are sufficient resources to implement a policy and implementers know what to do, implementation will still fail if the existing bureaucratic structure hinders the coordination needed to implement the policy.

According to the researcher, structural coordination is not a challenge in implementing $E$ government in DPMPPTSP. The bureaucratic structure in the DPMPPTSP which was given authority to the Deli Serdang Regent Regulation No. 2020 The year 2016 has cut the bureaucracy by one level by handing over the authority of the Regent to the Head of the DPMPPTSP. In this abridged bureaucratic structure, the DPMPPTSP can independently issue permits.

\section{REFERENCES}

Abidin. Zainal. 2010. Kebijakan Publik. Jakarta: Balai Pustaka. Boediono, B. 2003. Pelayanan Prima Perpajakan. Jakarta: Rineka Cipta.

Bungin, Burhan H.M,.2007. Penelitian Kualitatif: Komunikasi, Ekonomi, Kebijakan. Publik, dan IImu sosial. Jakarta: Kencana Prenama Media Group.

Devito, Joseph, A.1997. Human Communication. New York: Harper Collinc. Edward III, George C. 1980. Implementing public policy. Washington DC:

Congressional Quartely Press.

Hill, Michael dan Peter Hupe. 2002. Implementing Public Policy: Governance in Theory and in Practice. London: SAGE Publications.

Indrajit, Richardus Eko. 2006. Electronic Government Konsep Pelayanan Publik Berbasis Internet dan Teknologi Informasi. Yogyakarta: Andi.

Indrajit, Richardus Eko. 2007. Electronic Government in Action: Strategi Implementasi di Berbagai Negara. Yogyakarta: Andi.

Lester, James P. dan Joseph Stewart. 2000. Public Policy: An Evolutionary Approach Belmont: Wadsworth.

Lee, Nag Yeon dan Kwangsok Oh. e-Government Applications. Korea: United Nation Asian and Pacific Training Centre for Information and Communication Technology for Development (UN-APCICT).

Lembaga Administrasi Negara. 2003. SANKRI: Sistem Administrasi Negara Kesatuan Republik Indonesia, Volume 2. Jakarta: Lembaga Administrasi Negara. 
Lembaga Administrasi Negara. 2006. SANKRI: Sistem Administrasi Negara Kesatuan Republik Indonesia, Buku III. Jakarta: Lembaga Administrasi Negara.

Moleong, Lexy J. 2006. Metodelogi Penelitian Kualitatif. Bandung: Remaja Rosdakarya.

Mulyana, Deddy. 2003. Ilmu Komunikasi: Suatu Pengantara. Bandung: Remaja Rosdakarya.

Neuman. 2007. Social Research Methods. London: Pearson Education.

Ragani, A. Fifi Nurindah. 2016. Penerapan Electronic Government Pada Kantor Imigrasi Kelas I Makassar. Makasar: Universitas Hasanuddin.

Rianto, Budi, dan Tri Lestari. 2012. Aplikasi E-government dalam Pelayanan Publik. Surabaya: Putra Media Nusantara.

Rogers, Everett M. Dan Rekha Agarwala-Rogers. Communication in Organizations. Michigan: Free Press.

Sinambela, Lijan Poltak. 2006. Reformasi Pelayanan Publik: Teori, Kebijakan, dan Implementasi. Jakarta: PT. Bumi Aksara.

Singrimbung, Masri. 2006. Metode Penelitian Survey. Jakarta : LP3ES. Sugiyono. 2005. Metode Penelitian Administrasi. Bandung: Alfabeta.

Sugiyono. 2009. Metode Penelitian Bisnis (Pendekatan Kuantitatif, Kualitatif, dan R\&D. Bandung: Alfabeta.

United Nations, 2016. E-Government Survei 2016. New York: United Nations. Wibawa, Samodra, dkk. 1994. Evaluasi Keijakan Publik. Jakarta: PT. Raja Grafindo Persada.

Winarno, Budi. 2005. Teori dan Proses Kebijakan Publik. Yogyakarta: Media Pressindo.

Wirtz, Bernd W dan Peter Daiser. 2015. E-Government Strategy Process Instruments. Leipzig: Deutsche National bibliothek.

Asima, Yanti Siahaan. 2017. Challenges in Developing E-Government for Good Governace in North Sumatra

Annisa, Citra. 2011. Implementasi E-Government Melalui Bursa Kerja Online Pada Kementrian Tenaga Kerja dan Transmigrasi. Skripsi: Universitas Indonesia.

Hartono, dkk. 2010. Electronic Government Pemberdayaan Pemerintahan Dan Potensi Desa Berbasis Web. Jakarta : Jurnal Teknologi Informasi, Volume 6 Nomor 1.

Holle, Erick S. 2011. Pelayanan Publik Melalui Electronic Government: Upaya Meminimalisir Praktek Maladministrasi Dalam Meningkatan Public Service. Jurnal Sasi Vol.17 No.3.

Sudarto, Yudo. 2006. E-Goverment Dan Reformasi Birokrasi Menuju Pemerintahan Yang Baik. Bandung: Prosiding Konferensi Nasional Teknologi Informasi \& Komunikasi untuk Indonesia. Bandung: Prosiding Konferensi Nasional Teknologi Informasi \& Komunikasi untuk Indonesia. 